\section{ОСОБЕННОСТИ ОПИСАНИЯ СОЦИАЛЬНОГО СООБЩЕСТВА ГЛУХИХ ЛЮДЕЙ}

\section{Аннотация:}

Актуальность данного исследования обусловлена необходимостью социокультурного анализа глухих людей как малоизученной социальной группы с точки зрения социологии. В России в отношении глухих принято говорить «лица $c$ нарушением слуха", "лица с ограниченными возможностями здоровья по слуху», "глухонемые», «глухие», "слабослышащие» и т. п. В рамках планируемого исследования понятие «глухие» будет использоваться без акцентирования внимания на реальном состоянии слуховой функции. Члены сообщества әлухих испытывают дискриминацию со стороны слышащих: ущемление языковых прав, ущемление трудовых прав, наклеивание ярлыков наподобие «глухонемой - значит тупой, умственно отсталый», что влияет в целом на их жизнь в социуме. Огромное количество мифов, заблуждений в отношении данного сообщества приводит к ухудшению социализации глухих в мире слышащих.

Ключевые слова:

глухие, слабослышащие, русский жестовый язык, инклюзивная культура, культура глухих, сообщество глухих.

\section{FEATURES OF THE DESCRIPTION OF THE SOCIAL COMMUNITY OF DEAF PEOPLE}

Summary:

The relevance of this study is due to the need for sociocultural analysis of the deaf people as a poorly understood social group in terms of sociology. There is the tendency to say the terms "persons with hearing impairment", "persons with hearing disabilities", "deafmute", "deaf", "hard of hearing", etc. in Russia. In this study, the concept of "deaf" will be used without regard to the actual level of hearing. Members of the deaf community feel discrimination by hearing people: a violation of linguistic rights, a violation of the right to work, the name "deaf and dumb is stupid, mentally retarded", which affects their lives in society as a whole. A huge number of myths, delusions in relation to this community leads to a deterioration in the socialization of deaf in the world of hearing people.

В связи с тем, что в последнее время социологи отмечают изменения в социальной структуре общества, которое становится все более дифференцированным и одновременно гуманным, выделяющим ценность личности, под особо пристальным вниманием оказываются люди с ограниченными возможностями здоровья, в частности глухие. Выделение глухих в отдельную группу и интерес к данному сообществу продиктованы тем, что существует достаточно большое количество людей с ограничениями слуха, которые более активно, по сравнению с другими нозологическими группами, объединяются для решения собственных проблем. При наличии собственного языка, субкультуры и социальных сетей они привлекают внимание как социальный феномен.

В России в отношении глухих людей принято говорить «лица с нарушением слуха», «лица с ограниченными возможностями здоровья по слуху», «глухонемые», «глухие», «слабослышащие» и др. Важно отметить, что в рамках культурной концепции понимания глухоты [1, с. 165] корректнее использовать термин «глухие», который применяется представителями самого сообщества для самоопределения и самоидентификации. Также за рубежом используют термин «deaf gain» («обретение глухоты»), в отличие от постсоветского термина «нарушение слуха», который понимается как процесс приобретения новой идентичности глухого, принятия себя глухим как нормы социального существования [2].

Причины потери или нарушения слуха очень разнообразны: прием лекарственных средств, осложнение после различных болезней, травмы как в детском, так и во взрослом возрасте, наследственность и т. п. При этом наследственность - это не основной фактор, так как статистика по всем странам мира утверждает, что только 10\% глухих детей рождаются в семьях глухих, остальные 90\% - в семьях слышащих. По оценке на 2004 г., в мире насчитывалось 124,2 млн людей с потерей слуха всех возрастных групп в странах с высоким, средним и низким уровнем 
дохода. Также, по этой статистике, потеря и нарушение слуха являются наиболее распространенными причинами инвалидности. По данным Всемирной организации здравоохранения, к 2020 г. число людей с нарушением слуха увеличится на 30\% [3]. Согласно отчету Всемирной федерации глухих, на 2018 г. в России насчитывалось около 13 млн людей с нарушением слуха, тогда как членами Всероссийского общества глухих являются 150 тысяч человек. По данным Федеральной службы государственной статистики, на 1 января 2016 г. в России зарегистрировано 12,6 млн граждан, имеющих инвалидность. В 2015 г. поставлено на учет 12 тысяч инвалидов по слуху. Однако, по заявлениям Всероссийского общества глухих, примерно 8-9 млн человек по всей России имеют различные нарушения слуха. Среди них примерно 1,5 млн людей с тяжелым нарушением слуха и 250-300 тысяч - тотально глухих. Согласно выборочной статистике, на 2018 г. насчитывается порядка 1 млн детей и подростков с нарушением слуха. В России в период с 2015 по 2017 г. на учет по инвалидности по слуху были поставлены 77911 человек. Таким образом, имеющиеся данные не отражают реальную ситуацию. Так, в последнее время в общую статистику попадают также те, кто в раннем детстве получили медицинскую реабилитацию в виде кохлеарной имплантации, обучающиеся в массовых школах и, скорее всего, не являющиеся носителями культуры глухих.

В пункте 4 статьи 30 ратифицированной в 2012 г. Конвенции ООН о правах инвалидов указано, что «инвалиды имеют право наравне с другими на признание и поддержку их особой культурной и языковой самобытности, включая жестовые языки и культуру глухих» [4]. Тем не менее, члены сообщества глухих испытывают дискриминацию со стороны слышащих: ущемление языков прав, ущемление трудовых прав, наклеивание ярлыков наподобие «глухонемой - значит тупой, умственно отсталый», что влияет в целом на их жизнь в социуме. Огромное количество мифов, заблуждений в отношении этого сообщества приводит к ухудшению социализации глухих в мире слышащих. Зачастую именно в отношении данной категории инвалидности складывается большое количество стереотипов - про их язык, поведение, мировоззрение, психологию [5, с. 21]. Это связано с давно сложившимся типом общественного сознания, в котором понятие «инвалид» во все времена означало «непригодный к деятельности». Так как глухоты не видно, для того чтобы понять, что человек не слышит, надо вступить с ним в диалог или, возможно, увидеть у него слуховой аппарат. Таким образом, то, что не видно, является неясным и в результате порождает большое количество мифов, которые перерастают в заблуждения. Заблуждения формируют стереотипы, которые в результате ведут к непониманию, задержке формирования инклюзивной культуры.

Понятие «культура глухих» чаще всего определяется как жестовое пение, театры глухих. Под «социальным сообществом» чаще всего понимается группа людей, объединенных общими целями. Но понятие культуры любого сообщества, любой социальной группы значительно шире и включает в себя разные аспекты: манеру поведения, стиль жизни, общий исторический опыт, восприятие мира, убеждения, ценности и т. п. [6]. Говоря о глухих, в современном обществе культура меньшинства, которыми и являются глухие, определяется таким понятием, как «субкультура». Субкультура - понятие в социологии, антропологии и культурологии, обозначающее часть культуры общества, отличающейся своим поведением от преобладающего большинства, а также социальные группы носителей этой культуры. Субкультура может отличаться от доминирующей культуры собственной системой ценностей, языком, манерой поведения и другими аспектами. Различают субкультуры, формирующиеся на национальной, демографической, профессиональной, географической и других основах. В частности, субкультуры образуются этническими общностями, отличающимися своим языком или диалектом от общей языковой нормы [7, с. 470]. Так как российское сообщество глухих имеет свой язык, русский жестовый, и обладает набором критериев, отличным от российского сообщества большинства - слышащих, в рамках социокультурного анализа сообщества глухих необходимо определить, применимо ли понятие «субкультура» к данному сообществу.

История изучения сообщества глухих с точки зрения дефектологического подхода насчитывает много лет, однако с точки зрения социологического подхода и социокультурного анализа в России сообщество глухих практически не исследовалось. Впервые в 1996 г. А.З. Свердлов в своей диссертации определяет сообщество глухих по единственному критерию - «глухота» и рассматривает методики развития культуры у студентов через театральную деятельность [8]. В конце 90-х гг. некоторые упоминания о сообществе и культуре глухих Америки содержались в работах по лингвистике русского жестового языка Г.Л. Зайцевой. Одним из самых интересных описаний сообщества глухих является книга «Человек из мира тишины», авторы которой сами являются глухими [9]. Эта книга обобщила знания о культуре и сообществе глухих преимущественно в Европе и Америке, совсем поверхностно рассмотрев сообщество глухих в России. 
Также на тему сообщества глухих написано несколько статей научно-популярного характера исследователем А.А. Комаровой. О.О. Копнина в своей работе поднимает тему о законодательстве как фракторе формирования субкультуры глухих [10, с. 338]. Группой авторов (О.Л. Посух, М.С. Бады-Хоо и др.) рассматривается роль социально-демографической структуры сообщества глухих людей в распространенности наследуемых форм потери слуха, при этом при рассмотрении сообщества глухих данные авторы используют медицинский подход [11, с. 8]. Н.В. Большаков в своей работе пишет о трансформации научных подходов к пониманию глухоты - от девиации к идентичности, рассматривает основные научные дискурсы, в которых помещается понятие глухоты в XX-XXI веках, и выделяет три концепции глухоты: медицинскую, социальную и культурную [12, с. 160]. Первые две концепции в той или иной мере могут считаться универсальными для всех категорий людей с инвалидностью. Третья культурная концепция глухоты появилась благодаря признанию лингвистами жестового языка, и данная концепция определяет глухих как особую группу в исторических, культурологических и социологических терминах. Больше в научных источниках найти какие-либо работы, посвященные сообществу и культуре глухих, не удалось.

При определении критериев социальной группы глухих важно обратить внимание на важнейший критерий - наличие своего, отличающегося от других языка, что выделяет глухих, в соответствии с культурной концепцией, в особую группу. Признание лингвистами русского жестового языка полноценной лингвистической системой произошло в России на рубеже XXI века, хотя исследования его начались еще в 1980-х гг. Г.Л. Зайцевой. Русский жестовый язык официально признан языком людей с нарушением слуха, в том числе в сферах использования государственного языка Российской Федерации, только с 2013 г. [13]. Но понимание в российском обществе важности и ценности русского жестового языка в обучении, развитии и формировании личности глухого человека до сих пор отсутствует. Педагогическая система по-прежнему построена на медицинской и отчасти социальной концепции глухоты, в которой глухой человек рассматривается как девиант, а глухота анализируется как болезнь, или патология, которую необходимо лечить. Несмотря на ратифицированную Конвенцию ООН о правах инвалидов и Федеральный закон о русском жестовом языке глухих продолжают обучать устной речи, игнорируя использование национального жестового языка. Несмотря на все попытки образования сделать глухих людей «говорящими», между собой глухие общаются на своем жестовом языке, независимо от того, в каком возрасте они им овладели. «Без родного языка нет нормально сформированной личности, нет понятия собственного "Я", нет культуры и истории. Для огромного числа глухих, а также слабослышащих граждан РФ русский жестовый язык является первым, или родным, языком. Если ребенок родился в семье глухих - это первый и родной язык. Если его родители - слышащие не использовали жестовый язык в общении с ребенком и он ходил в детский сад, где его обучали устной речи, в большинстве случаев к моменту поступления в школу ребенок не овладевал русским языком как системой», - так пишет в своей работе Т.П. Давиденко, глухой исследователь, выросший в семье глухих [14, с. 25]. По утверждению Е.С. Снитко и А.Д. Маймаковой, «родной язык - это язык, на котором человек мыслит без дополнительного самоконтроля, с помощью которого легко и естественно выражает свои мысли и которым владеет с максимальной глубиной и полнотой, на котором ему легче, быстрее и проще мыслится, который является для него наиболее привычной и удобной формой выражения мысли и языкового общения» [15, с. 2].

Один из исследователей культуры глухих А.А. Комарова отмечает: «В англоязычной литературе разделяют понятия "Deaf" с большой буквы и "deaf" с маленькой, что в русском языке абсолютно невозможно отразить. Большая буква "D" отражает принадлежность глухих к одной "нации", ведь названия всех национальностей в английском языке пишутся с большой буквы, а в русском языке таких правил нет (китайцы, а не Китайцы, евреи, а не Евреи). В английском же языке слово "глухие" с маленькой буквы обозначает просто лиц с нарушенным слухом, которых не объединяет общая культура и общий жестовый язык.... Как перевести, например, Deafhood, обозначающее единение глухих, общий опыт многих глухих, осознание себя глухим? (Сравните: child $и$ childhood - ребенок и детство; mother и motherhood - мать и материнство). Этот термин явно объединяет глухих как социокультурную лингвистическую группу» [16, с. 14]. В связи со сменой взглядов на глухоту во второй половине XX века на Западе сформировалась особая академическая дисциплина Deaf Studies, для которой пока нет устоявшегося термина в русском языке, которая направлена на изучение социальной жизни сообщества глухих и отдельных глухих, включая антропологию, экономику, географию, историю, политологию, психологию, социальные исследования и социологию [17]. Также Deaf Studies включает научные исследования, связанные с глухотой, по всему миру. Изучение жизни глухих подразумевает изучение их культуры, жестовых языков, истории и прав человека. Те, кто присоединяются к этой области исследования, участвуют в содействии изменению взглядов и точек зрения более широкого общества в отношении глухих людей. Крупные центры Deaf Studies существуют в США, Англии, Германии, Нидерландах, 
Чехии, Новой Зеландии, Китае, Филиппинах. В США и Англии также функционируют ассоциации Deaf Studies. В России вопросами глухоты занимается Институт коррекционной педагогики Российской академии образования, история которого начинается с 1908 г. Институт является ведущим научным центром страны в области коррекционной педагогики и специальной психологии [18]. Задача института состоит в коррекции различных нарушений в рамках образования, в основном дошкольного и школьного, что подтверждает больше медицинскую и частично социальную концепции, нежели культурную концепцию глухоты. Исследования глухих ограничиваются возрастом от рождения до преимущественно 14-18 лет, не старше.

Существующие в России современные социологические исследования по инклюзии, инклюзивной культуре, инвалидности не изучают глухих людей как отдельную социальную группу со своими особенностями, хотя с 1980-х гг. появляются небольшие работы Г.Л. Зайцевой, В.А. Паленного, В.З. Базоева, Н.С. Чаушьян о выделении глухих в социолингвистическое меньшинство. К числу критериев данной социальной группы авторы относят общий исторический опыт, браки внутри группы, идентификацию себя с группой, наличие своего жестового языка, отличного от звукового языка страны, совокупность социальных убеждений, поведенческие нормы, наличие формальных и неформальных объединений и т. п. [19]. На Западе точка зрения, что глухота - это не медицинский диагноз, а отличие, возникла в 1971 г., чуть позже появился термин «культура глухих» для обозначения сообщества и были выделены его признаки - жестовый язык и брачные модели внутри сообщества. В дальнейшем многие западные исследователи ставят цель описать историю развития сообщества, анализируют идентичность данной группы. Эту проблематику поднимают культурологи, антропологи, социологи. Они применяют различные методы, чтобы исследовать и описать сообщество. При этом уклон делается больше на возможности, а не на недостатки глухоты. Таким образом, за рубежом глухота объясняется как особенность, способствующая самоопределению и идентификации членов социальной группы. Систематизирующий концепт социокультурной теории заключается в следующем: глухота - особое состояние человека, а отнюдь не патология [20, с. 164]. Российские исследователи и активисты сообщества глухих предпочитают рассматривать себя в этногрупповых терминах, но определяют ряд противоречий: глухота как наследственность проявляется только в $10 \%$ случаев, значит, культурная самобытность не может передаваться из поколения в поколение и сама культура глухих не является независимой [21]. В данных условиях мы можем говорить о существующей культуре глухих людей. При рассмотрении социальных взаимодействий внутри сообщества мы видим определенные критерии, формирующие культуру внутри сообщества глухих.

Наличие известных, но малоизученных аспектов сообщества глухих требует систематизации, проработанности, классификации и эмпирического сбора данных. Назревает необходимость менять отношение социума, состоящего в большинстве своем из слышащих, боящихся «мира тишины», к такому фрактору, как «глухота», и учить оценивать его не только как дефект в медицинском аспекте, но и как фрактор, влияющий на формирование своего сообщества и своей культуры. Такой путь прошли в свое время большинство стран мира. Без популяризации данной культуры, без осознания социальных проблем в результате устоявшихся стереотипов и заблуждений, без познания и принятия культуры глухих сообществом большинства мы еще долго не будем способствовать фрормированию инклюзивной культуры всего общества.

\section{Ссылки:}

1. Большаков Н.В. От девиации к идентичности: трансформация научных подходов к пониманию глухоты // Журнал социологии и социальной антропологии. 2016. Т. 19, № 2 (85). С. 160-174.

2. Bauman D.L., Murray J.J. Deaf Studies in the 21st Century: "Deaf-gain" and the Future of Human Diversity // The Oxford Handbook of Deaf Studies, Language, and Education / ed. by M. Marschark, P.E. Spencer. Oxford, 2010. P. $210-225$. https://doi.org/10.1093/oxfordhb/9780195390032.013.0014.

3. Положение инвалидов [Электронный ресурс] // Федеральная служба государственной статистики. Официальная статистика. URL: https://www.gks.ru/folder/13964 (дата обращения: 08.12.2019).

4. Конвенция о правах инвалидов [Электронный ресурс] // Официальный сайт Организации Объединенных Наций. URL: www.un.org/ru/documents/decl conv/conventions/disability.shtml (дата обращения: 11.09.2019).

5. Варинова О.А., Елфимова С.В. Что вы хотите узнать о глухих : учеб. пособие. Новосибирск: Изд-во НГТУ, 2014. 36 с.

6. Энциклопедия культурологии [Электронный ресурс] // Академик. URL: https://dic.academic.ru/contents.nsf/enc culture/ (дата обращения: 12.05.2019).

7. Социология: энциклопедия / сост. А.А. Грицанов [и др.]. Мн., 2003. 1312 с.

8. Свердлов А.З. Социально-культурная деятельность как средство развития сообщества глухих: автореф. дис. ... д-ра пед. наук. СПб.: 1996. 38 с.

9. Базоев В.3., Паленный В.А. Человек из мира тишины. М., 2002. 815 с.

10. Копнина О.О. Законодательство как фрактор формирования субкультуры глухих в Российской Федерации // Социальная политика и социология. 2013. № 3-1 (94). С. 338-347.

11. Посух О.Л. [и др.] Роль социально-демографической структуры сообществ глухих людей в распространенности наследуемых форм потери слуха // Вавиловский журнал генетики и селекции. 2016. № 20 (1). С. 7-15.

12. Большаков Н.В. Указ. соч. 
13. О внесении изменений в статьи 14 и 19 Федерального закона «О социальной защите инвалидов в Российской Федерации» [Электронный ресурс] : фредеральный закон от 30 дек. 2012 г. № 296. Доступ из справ.-правовой системы «КонсультантПлюс».

14. Давиденко Т.П. Роль жестового языка в фрормировании самосознания глухих // Русский жестовый язык и мы: сб. тр. круглого стола. М., 2012.

15. Снитко Е.С., Маймакова А.Д. Понятие родного языка и его интерпретация в современной лингвистике // Вестник факультета русского языка и литературы Университета китайской культуры. 2001. Вып. 3. С. 3-10.

16. Комарова А.А. О культуре глухих на английском языке // В едином строю. 2010. № 11. С. $14-15$.

17. Gertz G., Boudreault P. The SAGE Deaf Studies Encyclopedia. Singapore, 2016. 1128 p.

18. Об институте [Электронный ресурс] // Институт коррекционной педагогики. URL: https://ikprao.ru/institute/about-theinstitute (дата обращения: 08.12.2019)

19. Варинова О.А., Елфимова С.В. Указ. соч. ; Базоев В.З., Паленный В.А. Указ. соч.

20. Большаков Н.В. Указ. соч.

21. Базоев В.З., Паленный В.А. Указ. соч.

Редактор, переводчик: Меньшикова Екатерина Игоревна 